\title{
Anagrelide Hydrochloride
}

National Cancer Institute

\section{Source}

National Cancer Institute. Anagrelide Hydrochloride. NCI Thesaurus. Code C28826.

The hydrochloride salt of a synthetic quinazoline derivative, Anagrelide Hydrochloride reduces platelet production through a decrease in megakaryocyte maturation.

Anagrelide inhibits cyclic AMP phosphodiesterase, as well as ADP- and collagen-induced platelet aggregation. At therapeutic doses, it does not influence white cell counts or coagulation parameters. Anag relide is used for treatment of essential thrombocythemia to reduce elevated platelet counts and the risk of thrombosis. ( $\mathrm{NCIO4)}$ 